\title{
The Role of Agencies in Creating Network Approach in Higher Education
}

\section{Jelena Dujmović Bocka* Boris Bakota**}

\author{
https://doi.org/10.31297/hkju.21.4.4 \\ UDK: $\quad 35.072 .6: 378.4(497.5)$ \\ 342.97:378.4(497.5) \\ Review scientific paper / pregledni znanstveni rad \\ Received / primljeno: 13.12.2020. \\ Accepted/ prihvaćeno: 5.11.2021.
}

An analysis of different aspects regarding the creation of networks within the Croatian higher education system is presented in the paper. The larger part of the paper refers to the analysis of public services in general and the network approach in public administration in particular. The state of the higher education system is presented through the inclusion of market and network principles and the establishment of numerous actors in this field by which effectiveness of this field of public administration is trying to be improved. The aim of the detailed examinations is to pro-

* Jelena Dujmović Bocka, Assistant Professor, Faculty of Law, Josip Juraj Strossmayer University, Osijek, Croatia (docentica Pravnog fakulteta Sveučilišta Josipa Jurja Strossmayera u Osijeku, Hrvatska, email: jdujmovi@pravos.hr).

ORCID: https://orcid.org/0000-0002-0727-718X

** Boris Bakota, Full Professor, Faculty of Law, Josip Juraj Strossmayer University, Osijek, Croatia (redoviti profesor Pravnog fakulteta Sveučilišta Josipa Jurja Strossmayera u Osijeku, Hrvatska, email: bbakota@pravos.hr).

ORCID: https://orcid.org/0000-0002-2848-679X 
vide an overview of all relevant actors whose interactions and roles resemble network-like relationships. To examine the starting hypothesis that neo-managerial approach leads to networking within the higher education system, an empirical study was conducted at the Josip Juraj Strossmayer University in Osijek, Croatia among the teaching staff and students. The final chapters of the paper present and discuss research results which principally support the initial assumptions.

Keywords: public services, higher education system, network approach, agencification, public administration

\section{Introduction ${ }^{1}$}

The fact that the higher education system (HES) is undergoing constant changes produces the necessity to further research and analyse this extremely complex area with the aim of developing concrete tools for improving the effectiveness of this segment of public administration. The implementation of the Bologna Process in the HES has enabled the inclusion of various actors whose influence should contribute to the improvement of the three fundamental economic values - efficacy, effectiveness and efficiency (the so-called "three E values"). These economic values are becoming deeply incorporated in the HES while having consequences that are evident through the strong agencification process. Even though the agencification model in public administration has been frequently analysed, it has not, however, been sufficiently researched in the higher education field. The neo-managerial approach leads to the formation of network-like relationships within the system of higher education. The aim of this paper is to provide an overview of the agencies and other relevant

1 This paper is a product of work that has been fully supported by the Faculty of Law, Josip Juraj Strossmayer University of Osijek under the project no. IP - PRAVOS -16 "New Challenges in the Development of Public Services on Local and Regional Level". The paper was presented at the conference organised by the Croatian Academy of Legal Sciences "The Challenges of the Croatian Public Sector in the European Union" held in Osijek on 18 and 19 June 2015 under the title "The Influence of Networking within the System of Higher Education on the Effectiveness of Functioning of Public Administration". The empirical research was conducted for the purpose of the doctoral dissertation of the author Jelena Dujmović, who finished her doctoral studies in 2014 at the University of Zagreb (Dujmović, 2014). 
actors in the Croatian higher education system, to emphasise the importance of networks within the field, and finally to provide an answer to the question: is the neo-managerial approach responsible for the development of networks within the higher education system? The analysis indicates that this area has experienced significant changes in recent years. Moreover, it shows that the HES has been extensively influenced by the network approach. In what way and to what extent will be shown further in the paper.

The paper has been divided into several key sections which refer to: overview of the perception of public services earlier and today (classification of public services, their historical development process and modern trends ); the network approach - conceptual issues (features of administrative networks, higher education system networks, overview of network relationships within the system of higher education in the Republic of Croatia, overview of the agencies and other actors in the area of higher education in Croatia); presentation of the research on the existence of networks within the higher education system in Croatia through conducted empirical research and the discussion of findings in the concluding chapter.

\section{Perception of Public Services - Earlier and Today}

\subsection{The Nature and Categories of Public Services}

It is generally known that the notion of public services was conceived towards the end of the $19^{\text {th }}$ century and is closely connected with the practice of the French Council of State. The main motive for the conception and the development of public services was to make the affairs of common interest for citizens and the society more accessible and affordable. Since the origin of the institute of public service is found in the French theory, it is inevitable to mention the role of Léon Duguit in creating the concept of public services. According to him, the government is primarily a collection of public services. He considers that public services are all those activities whose suspension would likely cause certain social disturbances (Duguit, 1913). The fulfilment of general interest is acknowledged by the French theory as the central element in the content of public service, which means that the notion of general societal interest is the fundamental element in the definition of public service (Rivero, 1971, p. 397, according to Borković, 2002, p. 13). Public services or services of 
general interest, as they are referred to by the EU legislation, are activities of a certain degree of economic nature that are performed in the interest of the general public. Their key characteristics are their diversity, special regulatory regime, fulfilment of public interest, and the responsibility of public authorities for their proper functioning (Koprić et al., 2014).

There are two basic interpretations of public services to differentiate between: a) the formal notion of public service based on the (public) status of the provider, and b) the material notion of public service emphasising the nature of the service, which places general or public interest as its most important feature. Koprić and his colleagues consider the following to be the fundamental classification criteria for public services: the purpose criterion (specific services perceived as executing authority or as contributors to social benefit), market performance criterion (the extent to which market mechanisms are either partially or completely limited in their provision), criterion regarding the level of public administration at which public services are delivered (services performed by the national government, regional services and local services), and the legal status criterion (whether services are provided by public or private sector organisations) (Koprić et al., 2014).

In the legislation and policy documents of the European Union, services of general interest are classified into commercial (economic, market) and non-commercial (non-economic, non-market). When determining the social and legal elements of public service, the following questions arise: who assigns the character of public service to specific services, why is a specific service assigned with the character of public service, and in what way is it proclaimed public? Laubadere claims that the character of public service is assigned to a specific service by the political community. The most debatable question is determining the criteria according to which a specific service is proclaimed a public service. The following criteria are frequently mentioned in the literature: continuity, non-mercantilism, and the fact that their function has to be of general interest. Since the mentioned criteria have not been widely accepted, it is to be concluded that there is no general definition to indicate the basic features of public services. Despite that, the following principles for managing public services are presented in the literature: the principle of continuity - public service needs to function continuously, the principle of adjustability - public service has to be able to adjust to the changing needs of public law, the principle of primacy - public service has to have advantage over private service, and the principle of non-mercantilism - public service must not have financial gain as its primary goal (Laubadere, 1969, p. 27, according 
to Borković, 2002, p. 16). It is important to mention that the character of public service is allocated by a general act or legal norm ${ }^{2}$ whereby the decision on whether a service receives such character strongly depends on the importance of the service within a community, as Krbek claims. Moreover, Krbek emphasises that such a perception is susceptible to change (Krbek, 1932).

\subsection{The Development of Public Services}

The development of public services has been influenced by the processes of urbanisation and industrialisation (referring to the period from the middle of the $19^{\text {th }}$ century) which decisively changed the structure of the European society and government organisation. They stimulated the development of new public needs in the areas such as public transport, communications, utility services, education, social protection and similar. Until then, the term government had mainly been used to describe the institutional mechanism for ensuring order in the community. The service role of the government strongly developed in the second half of the $19^{\text {th }}$ and the beginning of the $20^{\text {th }}$ century. From that period on, some theorists, therefore, perceive government as a collection of public services (Duguit, 1913). Some public services were being developed outside public institutions (e.g. education, different forms of ensuring fundamental social risks, utilities and similar), while others were originally developed by public authorities.

In the last quarter of the $20^{\text {th }}$ century, several factors caused a change in the perception of public services such as managerial reforms of public administration, crisis in the budgetary financing public services, informatisation, strengthening of EU institutions, expansion of the EU to transitional countries of central and eastern Europe and similar (Koprić et al., 2014). Managerial reforms of public administration are centred around economic values implemented in the public sector (efficiency, efficacy and effectiveness). During this period, the concept of a welfare state has slowly been substituted by a minimalist, regulatory state. Based on the latter concept, the state should be oriented towards regulation, supervision

${ }^{2}$ Borković points out that in France there is a principle that public services can only be established by law and that the situation is similar in Belgium too, where the legislator is responsible for its establishment in accordance with special or general law regarding public services (Borković, 2002, p. 16). 
and ensurance of the functioning of market mechanisms (Cananea, 2002, according to Koprić et al., 2014, p. 221). New public management is a "strange marriage between the celebration of managerialism based on the import of management techniques from the private sector and increased marketisation of the public sector through a combination of privatisation and contracting out and commercialisation of the remaining public activities" (Hood, 1991, p. 5-6), or "an alternative paradigm may well offer a more realistic approach than the traditional model of public administration, but managerialism has not been without controversy" (Hughes, 1998, p. 53). The marketisation of public services has the potential to integrate a number of distinctive public management challenges (include the implementation of their strategic positioning) (McLaughlin, Osborne \& Chew, 2009).

The influence of these concepts on public services is visible through several trends of their modern development: liberalisation, privatisation, deregulation, and economic pricing. Liberalisation refers to the elimination of the public monopoly that has existed in a particular public service sector, which means opening markets for specific public services to other (private) actors as well. It is believed, from the perspective of Koprić and his colleagues, that competition between the bidders will lead to an increase of quality and reduction of prices of the services in question. The deregulation trend is closely connected with liberalisation and refers to a decrease in the legal regulation of specific services. Privatisation refers to a change of the ownership structure of public service providers whereby public-private partnerships, concession for longer periods of time and similar are considered the main forms of privatisation of public services. Economic pricing is quite often defined as charging full market prices for public services (Koprić et al., 2014).

\section{The Network Approach in Public Administration}

Network theories seem highly applicable for the investigation of actors in the higher education system as they are perceived as interacting agents with substantial autonomy (Nugaras \& Ginevičius, 2015; Niedlich et al., 2020). The network society is, according to Castells, "a special form of social structure ... which is a feature of the information era" (Castells, 2000, p. 5). Pusić highlights the importance of the network approach by the following statement: "The main new structure in the society of the 
information era, which was enabled or at least largely simplified by the information technology, is the network" (Pusić, 2005, pp. 33-34). Börzel (1998) considers the policy network a collection of relatively stable relations of non-hierarchical and interdependent nature connecting numerous subjects. Peterson (2003, p. 1) claims that a network is "a group of different subjects connected in political, social and economic life". Žugaj and colleagues claim that "network is in its nature an organic communication process in which there is no hierarchical structure, everyone is free and mutually independent, while responsibility and power are horizontally dispersed" (Žugaj, Šehanović \& Cingula, 2004, p. 231).

When discussing the term administrative networks, Đulabić (2011) cites a variety of definitions from a number of authors. The following definitions of administrative networks seem to be the most significant ones: a) "cluster or the complexity of organisations, different from other clusters and complexities, mutually connected by depending on means and breaks within the structure of dependence on means" or "sets of formal and informal institutional relations between governmental and other subjects structured around endlessly negotiated beliefs and interests in forming public policies and their implementation..." (Rhodes, 1990, p. 304; 2007, p. 2), b) "more or less stable forms of social relations between interdependent subjects, which are shaped around individual public problem and/or state budget" (Kickert, Klijn \& Koopenjan, 1997, p. 6), c) "a systematic set of relations between political subjects sharing common interest or general orientation in a specific area" (Heywood, 2019, p. 358), d) Peterson - "a group of different types of subjects mutually connected in political, social and economic life" (Peterson, 2003, p. 1). ${ }^{3}$

Some of the most important features of administrative networks are: 1 . Interdependency - every actor participating in the policy process is constrained by the available resources and dependent on others (Kim, 2003). Interdependency creates interaction between different subjects and stimulates dynamic relations within the network; 2. Pluriformity - networks in public policies are composed of a variety of different actors with different legal positions: public sector actors from various territorial levels, private firms and various civil society associations; 3 . Interest heterogeneity - all the subjects within the network are interested in a specific public problem from their own point of view. Every subject within the network has a de-

${ }^{3}$ More about the mentioned definitions of the term administrative networks (Đulabić, 2011, pp. 29-31) 
gree of autonomy in comparison to other subjects and its own strategies on how to achieve the goals that were set; 4 . Institutionalisation - communication between the subjects is stable, emphasis is put on mechanisms for connecting subjects within the network for easier information exchange and achieving arrangements. It is possible to diversify networks based on their establishment: formal (relation of interdependent connection is formally created - i.e. by laws, contracts and similar) and non-formal (based on individual relations regarding a specific public problem). (more in: Đulabić, 2011)

Arguably all these features are present in contemporary higher education systems. According to Buratović (2009), the system of higher education consists of various and numerous actors: ministry and agencies, public and private universities, students, institutions for professional development of experts regarding applied knowledge etc. The same author claims that the existing organisational forms do not possess the quality that is sufficient for the stimulation of societal development. Provided that societies prefer faster development, they need to stimulate their citizens and students to engage in higher education. Buratović continues that in that case private and public universities could gain a lot of competition, whereas students and citizens would have access to cheaper and more quality forms of education (external consultants, professional associations, individual professional experts and teachers of public universities could be the new entrepreneurs in higher education who desire to join the more affordable, private sector). On the other hand, the government should, as the representative of the society, stimulate the competition in higher education regardless of how efficient the current organisational forms are. This could result in the establishment of new and numerous actors and further complicate structures of the existing networks and even create new ones. ${ }^{4}$

${ }^{4}$ Buratović points out that there are two processes when managing organisations, the development of the system and directing people to use organisational instructions and tasks (Buratović, 2010, p. 126). "In the UK, the Higher Education Innovation Fund financially supports higher education institutions in knowledge exchange and productive interactions with business ..." (Jongbloed, Enders \& Salerno, 2008, p. 315). "Students, parents, employers, professional bodies, governments and other policy or funding bodies, as well as universities and the disciplines themselves, have a strong interest in ensuring good academic governance and high-quality offerings" (Naylor, Dollinger, Mahat \& Khawaya, 2020, pp. 2-3). 


\section{Actors in the Croatian System of Higher Education}

Figure 1 should be carefully observed as it presents all groups of relevant actors currently existing in the Croatian higher education area (see Figure 1). It contains the ministry responsible for the area of higher education, agencies, universities (faculties, academies of arts), polytechnics and colleges. The following sub-sections present these actors and their roles in this field.

Figure 1: Subjects in the area of bigher education in the Republic of Croatia

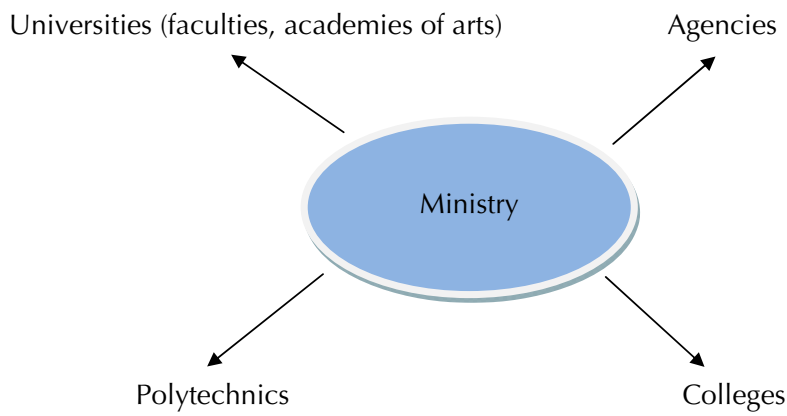

Source: Authors.

Ministries are large and multifunctional organisations that integrate policy making, regulatory and implementation functions and that are subjected to hierarchical control and political leadership. They are a part of the state administration system, financed primarily from the state budget, and their employees are predominantly civil servants (Koprić et al., 2014). The Ministry of Science and Education (hereinafter: MSE) is responsible for the services provided within the higher education system while simultaneously performing administrative and other tasks, which refer to: the development of higher education, implementation of national strategies and higher education programmes, ensuring and supervising financial and material conditions for the proper functioning of universities etc. ${ }^{5}$

5 This Ministry performs, among other things, tasks related to: preschool system, primary and secondary school systems in the country and abroad; National Curriculum; textbooks, regulations and standards and other requirements related to educational work; development of the school system, student standard; inspections; establishing and supervising the legality of educational institutions; providing financial and material means for the 
MSE consists of: Cabinet of the Minister, Secretariat of the Ministry, Department of Science and Technology, Department of Higher Education, Department of Education and Training, Department of Support and Promotion of the Education System, Independent Sector for Inspection, Independent Sector for Legal Affairs, Independent Sector for National Minorities, Independent Service for Coordination of Politics, European Affairs and International Cooperation, and Independent Service for Internal Audit. The Department for Higher Education has been established within the Ministry to perform tasks from the area of higher education. The following sectors have been organised within the department: 1) Sector for Higher Education Institutions and Student Standard, and 2) Sector for Higher Education Development.

The term agencification denotes the trend in contemporary administrative development in numerous countries since the beginning of the 1980s which is characterised by the formation of administrative organisations similar to agencies. Agencification, as a form of administrative (horizontal) decentralisation, has been facilitated by general political and economic development, globalisation and Europeanisation process. Some of the key reasons for the establishment of agencies are of technical, political and democratic nature (more in: Koprić et al., 2014, pp. 197-199). Agency is a type of administrative organisation formed in the process of administrative decentralisation by the assignment of various public tasks from the central state administration to structurally detached organisations with a certain degree of autonomy. Functionally, the existing administrative tasks are being transferred to an existing independent organisation. These are the key features of agencies: they are structurally separated from the hierarchical structure of the central state administration; their tasks are of public nature; employees usually have the status of civil servants; they are financed mostly from the state budget; a specific degree of their autonomy is protected by mechanisms that guarantee their managerial-organisational, financial, legal and policy autonomy; a particular level of control of the agencies is ensured by means of political-democratic, legal and financial control. There are two basic types of agencies: executive and regulatory. Executive agencies are established by the executive branch of government and they mostly perform executive tasks. It is possible to

education system etc. The Ministry performs administrative and other tasks regarding: the development of the science and technology system; development of scientific and other legal persons; application of scientific achievements in particular areas etc. More in the Act on the Organisation and Scope of Central State Administration Bodies (2020). 
distinguish between several subtypes of executive agencies, such as expert agencies, whose purpose is to provide support and supervise the implementation of public policies, and allocation agencies which allocate the financial means according to pre-determined criteria to particular groups of users. Furthermore, besides executive agencies, there are regulatory agencies - established by legislative authority and controlled by it for the purposes of regulating a particular market by determining standards and rules, deciding in individual cases, and solving conflicts between service providers (Koprić et al., 2014).

There are currently four agencies existing in the area of education in the Republic of Croatia: Agency for Science and Higher Education, Agency for Education and Teacher Training, Agency for Mobility and EU Programmes, and Agency for Vocational and Adult Education. In the following paragraphs, the Agency for Science and Higher Education and the Agency for Mobility and EU Programmes will be presented more closely. Furthermore, there are other important actors in the area of higher education that need to be presented for the complete picture of the HES in Croatia. These are the National Council for Science, Higher Education and Technological Development, Council for Financing Scientific Activity and Higher Education, and the Ethics Committee in Science and Higher Education.

Agency for Science and Higher Education. The Agency for Science and Higher Education was founded by the Croatian Government in 2004 as an independent and autonomous body which performs tasks within the jurisdiction and competence determined by three acts: Act on Quality Assurance in Science and Higher Education, Science and Higher Education Act, and Act on Recognition of Foreign Educational Qualifications. The main tasks of this agency are related to the external evaluation of institutions and programmes within the system of science and higher education. ENIC/NARIC National Office is incorporated within the Agency - information centre for academic mobility and recognition of higher education qualifications; it is a member of the European Network of Information Centres. The Agency performs all of its activities in accordance with European standards and guidelines as well as with international best practices of quality in science and higher education. Besides these, the Agency for Science and Higher Education also deals with: initial accreditation procedures, re-accreditation procedures, thematic evaluation, audit of higher education institutions (the procedures of external independent periodic evaluation of inner systems for ensuring and promoting quality), gathering and processing information about the system of science and 
higher education for the purpose of developing strategic decisions and other related activities. ${ }^{6}$

Agency for Mobility and EU Programmes. The Agency for Mobility and EU Programmes is a public institution established by the Government of the Republic of Croatia in 2007 with the aim of creating an institutional framework for the implementation of the two largest programmes of the European Union in the area of education and training - Lifelong Learning Programme and Youth in Action Programme. The mission of the Agency is declared on its official website - to support internationalisation with the aim of promoting quality within the system of science, education and training along with managing benefits for youth in Croatia according to the needs of citizens, society and economy and its vision - ensuring the possibilities for mobility and international cooperation in the area of science, education, training and youth and strengthening of human and democratic potential, social cohesion and competitiveness of the Croatian society. ${ }^{7}$

National Council for Science, Higher Education and Technological Development. The National Council for Science, Higher Education and Technological Development is the highest advisory body for the development and quality of the entire system of science, higher education and technological development which also: discusses issues of relevance for the whole system while proposing measures and encouraging their implementation, proposes measures for improvement of higher education, and other similar tasks.

Council for Financing Scientific Activity and Higher Education. The Council for Financing Scientific Activity and Higher Education is an advisory body of the National Council for Science, Higher Education and Technological Development which proposes criteria for the distribution of budgetary resources for scientific activities and higher education that are then allocated by national councils. ${ }^{8}$

Ethics Committee in Science and Higher Education. The Ethics Committee in Science and Higher Education is the highest advisory and professional body for promoting ethical principles and values in science and higher education, in business and public relations, in application of modern

${ }^{6}$ Other information is available on the official website of the Agency for Science and Higher Education https://www.azvo.hr/hr/o-nama

7 The official website of the mentioned Agency is https://www.mobilnost.hr/

${ }^{8}$ See https://www.azvo.hr/hr/savjet-za-financiranje-znanstvene-djelatnosti-i-visokogobrazovanja 
technologies as well as in environmental protection. In its meetings, the Committee expresses its opinions and viewpoints regarding the ethical acceptability of the revised cases in the form of opinions, decisions, references, propositions or remarks. ${ }^{9}$

\section{Research on the Existence of Networks within the Higher Education System in Croatia}

\subsection{Methodology of the Research}

The existence of networks within the HES in Croatia was examined by the following hypothesis: the neo-managerial approach leads to forming network relationships within the system of higher education. Data was gathered through a questionnaire for professors, assistants and students of the Josip Juraj Strossmayer University of Osijek in 2014. The original questionnaire was comprised of three parts. In the first part, respondents were asked to provide their personal information (by circling one of the already given answers), the second part contained 23 statements in the form of multiple-choice questions (Likert scale, close-ended questions). The respondents were asked to express the degree to which they agree or disagree with a particular statement. In the third part of the questionnaire, the participants were given the chance to express their own remarks, suggestions and compliments regarding the previously mentioned statements. The research included 764 respondents altogether, 150 professors and 614 students. It encompassed all 17 faculties that are organisational constituents of the Josip Juraj Strossmayer University in Osijek, Croatia. Regarding the topic of this paper and the starting hypothesis, five statements from the questionnaire have been extracted and presented in the following paragraphs. These are the propositions that operationalise the main hypothesis:

1. The Agency for Science and Higher Education positively affects the development of higher education;

2. Science in Croatia would develop as fast even if agencies in the area of higher education did not exist (Agency for Science and Higher Education, Agency for Mobility and EU Programmes);

3. The Ministry of Science and Education involves other subjects in the area of higher education (universities, colleges, Agency for Science

${ }^{9}$ More at https://www.azvo.hr/hr/odbor-za-etiku 
and Higher Education, Agency for Mobility and EU Programmes, student associations) in forming and implementing higher education politics in Croatia;

4. The quality of higher education is impossible without intensive cooperation of the key subjects in the area of higher education (the competent Ministry and other ministries, universities, colleges, Agency for Science and Higher Education, Agency for Mobility and EU Programmes, student associations);

5. I consider that the financing of universities should be regulated by programme contracts which determine long-term strategic goals through agreements between the Ministry and universities.

The gathered data was processed separately for each category of respondents.

\subsection{Research Results - Professors and Assistants}

Half of the surveyed professors and assistants concur with the statement that the Agency for Science and Higher Education positively affects the development of higher education in general, and there is a statistically significant difference in the distribution of the surveyed participants regarding the mentioned statement $\left(\chi^{2}\right.$ test, $\left.\mathrm{p}<0,05\right)$. The distribution of the answers to the statement that science in Croatia would develop equally even without the agencies in the area of higher education (Agency for Science and Higher Education and Agency for Mobility and EU Programmes) is quite even, however, the largest part of the participants, 55 (37\%), do not agree with this statement. Also, there is a similar distribution of answers regarding the statement that the Ministry of Science and Education significantly involves other subjects in the area of higher education (university colleges, Agency for science and Higher Education, Agency for Mobility and EU Programmes, student associations) in forming and implementing higher education policies in Croatia whereby 54 (36\%) participants do not have a clear attitude, which means they neither agree nor disagree with this statement. 116 (77\%) participants agree with the statement that the quality of higher education is impossible without intensive cooperation of the key subjects in the area of higher education (the Ministry and other ministries, universities, colleges, Agency for Science and Higher Education, Agency for Mobility and EU Programmes, student associations), whereas 99 (66\%) participants consider that the financing of universities should be regulated by programme contracts which determine long-term strategic goals through agreement between 
the Ministry and university. It is visible from the presented figures that the last two statements show a statistically significant distribution of the participants' attitudes $\left(\chi^{2}\right.$ test, $\left.\mathrm{p}<0.05\right)$ (see Table 1 ).

\section{Table 1: Research results (professors and assistants)}

\begin{tabular}{|c|c|c|c|}
\hline & $\begin{array}{c}\text { I completely } \\
\text { disagree + } \\
\text { I mostly } \\
\text { disagree }\end{array}$ & $\begin{array}{l}\text { I neither } \\
\text { agree nor } \\
\text { disagree }\end{array}$ & $\begin{array}{c}\text { I mostly } \\
\text { agree }+ \\
\text { I completely } \\
\text { agree }\end{array}$ \\
\hline $\begin{array}{l}\text { 1. The Agency for Science and Higher } \\
\text { Education positively affects the devel- } \\
\text { opment of higher education }\end{array}$ & $\begin{array}{c}25 \\
(17 \%)\end{array}$ & $\begin{array}{c}50 \\
(33 \%)\end{array}$ & $\begin{array}{c}75 \\
(50 \%)\end{array}$ \\
\hline $\begin{array}{l}\text { 2. Science in Croatia would develop as } \\
\text { fast even if agencies in the area of } \\
\text { higher education did not exist (Agen- } \\
\text { cy for Science and Higher Education, } \\
\text { Agency for Mobility and EU Pro- } \\
\text { grammes); }\end{array}$ & $\begin{array}{c}55 \\
(37 \%)\end{array}$ & $\begin{array}{c}47 \\
(31 \%)\end{array}$ & $\begin{array}{c}48 \\
(32 \%)\end{array}$ \\
\hline $\begin{array}{l}\text { 3. The Ministry of Science and Educa- } \\
\text { tion involves other subjects in the area } \\
\text { of higher education (universities, col- } \\
\text { leges, Agency for Science and Higher } \\
\text { Education, Agency for Mobility and } \\
\text { EU Programmes, student associa- } \\
\text { tions) in forming and implementing } \\
\text { of higher education politics in Croatia }\end{array}$ & $\begin{array}{c}44 \\
(29 \%)\end{array}$ & $\begin{array}{c}54 \\
(36 \%)\end{array}$ & $\begin{array}{c}52 \\
(35 \%)\end{array}$ \\
\hline $\begin{array}{l}\text { 4. The quality of higher education is im- } \\
\text { possible without intensive cooperation } \\
\text { of the key subjects in the area of higher } \\
\text { education (the related Ministry and } \\
\text { other ministries, universities, colleges, } \\
\text { Agency for Science and Higher Edu- } \\
\text { cation, Agency for Mobility and EU } \\
\text { Programmes, student associations) }\end{array}$ & $\begin{array}{c}11 \\
(7 \%)\end{array}$ & $\begin{array}{c}23 \\
(16 \%)\end{array}$ & $\begin{array}{c}116 \\
(77 \%)\end{array}$ \\
\hline $\begin{array}{l}\text { 5. I consider that the financing of universi- } \\
\text { ties should be regulated by programme } \\
\text { contracts which determine long-term } \\
\text { strategic goals through agreements be- } \\
\text { tween the Ministry and universities }\end{array}$ & $\begin{array}{c}14 \\
(9 \%)\end{array}$ & $\begin{array}{c}37 \\
(35 \%)\end{array}$ & $\begin{array}{c}99 \\
(66 \%)\end{array}$ \\
\hline
\end{tabular}

Source: Authors. 


\subsection{Research Results - Students}

The opinions of students about the proposed statements are presented in Table 2. From the total number of 614 students who participated in the research, 289 students (46\%) agree with the statement that the Agency for Science and Higher Education positively affects the development of higher education, whereas 241 of them (39\%) neither agree nor disagree with the statement that science in Croatia would develop equally if it were not for agencies in the area of higher education. In addition, students do not have a clear opinion about the statement that the Ministry of Science and Education significantly involves other subjects in the area of higher education (university colleges, Agency for science and Higher Education, Agency for Mobility and EU Programmes, student associations) in forming and implementing higher education politics in Croatia, so 298 (49\%) neither agree nor disagree with this statement. Most of the students (56\%), however, do think that the quality of higher education is impossible without intensive cooperation of the key subjects in the area of higher education (the competent Ministry and other ministries, university colleges, Agency for Science and Higher Education, Agency for Mobility and EU Programmes, student associations), while 402 students (65\%) agree with the statement that the financing of universities should be regulated by programme contracts which determine long-term strategic goals through agreement between the Ministry and university. There is a statistically significant difference in the distribution of attitudes $\left(\chi^{2}\right.$ test, $\mathrm{p}<$ 0.05 ) regarding all the mentioned statements (see Table 2).

Table 2: Research results (students)

\begin{tabular}{|l|c|c|c|}
\hline & $\begin{array}{c}\text { I completely } \\
\text { disagree } \\
\text { I mostly } \\
\text { disagree }\end{array}$ & $\begin{array}{c}\text { I neither } \\
\text { agree nor } \\
\text { disagree }\end{array}$ & $\begin{array}{c}\text { I mostly } \\
\text { agree } \\
\text { I completely } \\
\text { agree }\end{array}$ \\
\hline $\begin{array}{l}\text { 1. The Agency for Science and Higher } \\
\text { Education positively affects the devel- } \\
\text { opment of higher education }\end{array}$ & $\begin{array}{c}9 \\
(15 \%)\end{array}$ & $\begin{array}{c}239 \\
(39 \%)\end{array}$ & 280 \\
\hline $\begin{array}{l}\text { 2. Science in Croatia would develop as } \\
\text { fast even if agencies in the area of } \\
\text { higher education did not exist (Agen- } \\
\text { cy for Science and Higher Education, } \\
\text { Agency for Mobility and EU Pro- } \\
\text { grammes); }\end{array}$ & $\begin{array}{c}224 \\
(37 \%)\end{array}$ & $\begin{array}{c}241 \\
(39 \%)\end{array}$ & $\begin{array}{c}149 \\
(24 \%)\end{array}$ \\
\hline
\end{tabular}


3. The Ministry of Science and Education involves other subjects in the area of higher education (universities, colleges, Agency for Science and Higher Education, Agency for Mobility and EU Programmes, student associations) in forming and implementing of higher education politics in Croatia

4. The quality of higher education is impossible without intensive cooperation of the key subjects in the area of higher education (the related Ministry and other ministries, universities, colleges, Agency for Science and Higher Education, Agency for Mobility and EU Programmes, student associations)

5. I consider that the financing of universities should be regulated by programme contracts which determine long-term strategic goals through agreements between the Ministry and universities

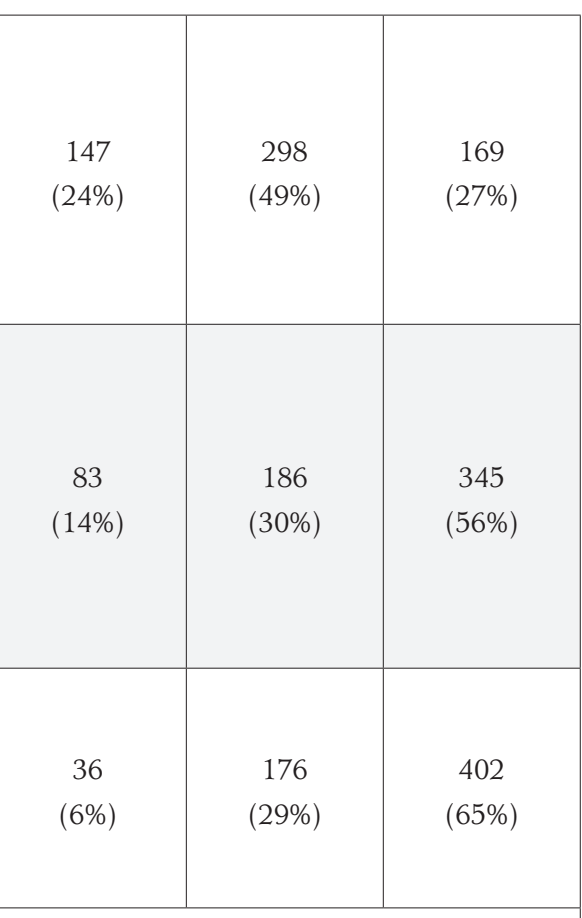

19. $\chi^{2}=92.25, \mathrm{p}<0.05 ; 2 . \chi^{2}=23.42, \mathrm{p}<0.05 ; 5 . \chi^{2}=65.03, \mathrm{p}<0.05 ; 17 \cdot \chi^{2}=170.25, \mathrm{p}<$ $0.05 ; 11 . \chi^{2}=333.28, \mathrm{p}<0.05$

Source: Authors.

\section{Conclusion}

It was not possible to make a general conclusion regarding the hypothesis that the neo-managerial approach leads to the formation of network relationships within the system of higher education. The hypothesis could, however, be considered partially confirmed by the teaching staff. Moreover, $50 \%$ of the teachers who participated in the research, agree with the statement that the Agency for Science and Higher Education positively affects the development of higher education, $77 \%$ of the professors support the statement that quality of higher education is impossible without intensive cooperation of the key subjects in the area of higher education (the competent Ministry and other ministries, university colleges, Agency for Science and Higher Education, Agency for Mobility and EU Programmes, student associations), whereas $66 \%$ of them think that 
the financing of universities should be regulated by programme contracts which determine long-term strategic goals through agreement between the Ministry and university. The remaining two statements could not be supported; therefore, these propositions are partially confirmed by the members of the teaching staff. Students share similar opinions as teachers since the majority agree with the mentioned statements, while they do not have a clear opinion about the remaining two statements, even though statistical tests show the difference in the distribution of answers for these two statements. Considering that a larger percentage of students support the mentioned statements, it can be concluded that the hypotheses are in general confirmed by students.

The organisational system of higher education has been revolutionised in recent years regarding the changes caused by intensive agencification. Besides the line Ministry, agencies have and other subjects create a networked system within the area of higher education. The importance of the network approach in the administrative science is becoming more evident. Networks, as a means of designing and managing public policies, have become quite popular as an organising method and their importance is still growing in particular segments of public administration. As is shown in the paper, there are different subjects relevant for the area of higher education. The current organisational forms are sufficient for improving the system of higher education. The Ministry of Science and Education, Agency for Science and Higher Education, Agency for Mobility and EU Programmes, public and private universities, student associations are all relevant subjects in the area of higher education. It is yet to be seen whether the network system in higher education will increase or reduce its membership in the foreseeable future.

The fact is that the number of relationships in the system of higher education is constantly growing. It would, therefore, be advisable to research which relevant subjects are there in the area of higher education, what role they have and what their aims are. The existence of different subjects with different aims within the system of higher education could potentially cause problems. Thus, it is necessary to think about the following:

1. Whether these subjects solve the existing problems in the area of higher education and in what way;

2. Whether these subjects solve these problems actively and/or passively;

3. Whether these subjects cooperate within the area of higher education;

4. Whether there is an interactive relationship between all the subjects in the area of higher education; 
5. Whether the Ministry of Science and Education imposes its own solutions on other subjects within the network;

6. Whether other subjects accept the proposed solutions or have their own propositions for solving the problems and similar.

Based on the presented research and analysis, it is to be concluded that in Croatia a developed network within the system of higher education does exist and that there is a possibility to further develop it.

\section{References}

Borković, I. (2002). Upravno pravo, VII. izmijenjeno i dopunjeno izdanje [Administrative law, $7^{\text {th }}$ amended version]. Zagreb, Hrvatska: Narodne novine.

Buratović, V. (2009). Jesu li državna sveučilišta glupa? [Are public universities stupid?]. Zagreb, Hrvatska: Naklada Jesenski i Turk.

Buratović, V. (2010). Rajski studij, Vrbunsko visoko obrazovanje [Paradise studies, Excellent higher education]. Zagreb, Hrvatska: Naklada Jesenski i Turk.

Börzel, T. (1998). Organizing Babylon - on the different conceptions of policy networks. Public Administration, 76(2), 253-273, https://doi.org/10.1111/14679299.00100

Cananea, G. (2002). The regulation of public services in Italy. International Review of Administrative Sciences, 68(1), 73-93.

Castells, M. (2000). Materials for an exploratory theory of the network society. British Journal of Sociology, 51(1), 5-24, https://doi.org/10.1080/000713100358408

Duguit, L. (1913). Les transformations du droit public [Transformacije javnog prava]. Paris, France: Librairie Armand Colin.

Dujmović, J. (3 December 2014). Visoko obrazovanje kao javna služba [Higher education as a public service] [doctoral dissertation]. University of Zagreb.

Đulabić, V. (3 March 2011). Utjecaj institucionalnog okvira regionalne politike na regionalnu samoupravu [The impact of the institutional framework for regional policy on regional self-government] [doctoral dissertation]. University of Zagreb.

Heywood, A. (2019). Politika [Politics]. Zagreb, Hrvatska: MATE d.o.o.

Hood, C. (1991). A public management for all seasons? Public Administration, 69, 3-19, https://doi.org/10.1111/j.1467-9299.1991.tb00779.x

Hughes, O. E. (1998). New public management \& administration. Retrieved from https://link.springer.com/chapter/10.1007/978-1-349-26896-2_3, 25.11.2020

Jongbloed, B., Enders, J., \& Salerno, C. (2008). Higher education and its communities: Interconnections, interdependencies and a research agenda. Higher Education, 56, 303-324, https://doi.org/10.1007/s10734-008-9128-2

Kickert, W. J. M., Klijn, E. H. \& Koppenjan J. F. M. (1997). Managing complex networks. London, UK: Sage. 
Koprić, I., Marčetić, G., Musa, A., Đulabić, V., \& Lalić Novak, G. (2014). Upravna znanost - Javna uprava u suvremenom europskom kontekstu [Administrative science: Public administration in the European context]. Zagreb, Hrvatska: Pravni fakultet, Studijski centar za javnu upravu i financije.

Krbek, I. (1932). Upravno pravo; Organizacija javne uprave, knjiga II [Administrative law: Organisation of public administration, II]. Zagreb, Hrvatska: Tisak i naklada Jugoslavenske štampe.

Laubadêre, A. de (1969). Manuel de droit administratif, neuvieme edition [Administrative law handbook, $9^{\text {th }}$ edition], Paris, France: Librairie generale de droit et de jurisprudence.

McLaughlin, K, Osborne, S., Chew, C. (2009). Relationship marketing, relational capital and the future of marketing in public service organizations. Public Money \& Management, 29(1), 35-42, https://doi.org/10.1080/09540960802617343

Naylor, R., Dollinger, M., Mahat, M., \& Khawaya, M. (2020). Students as customers versus as active agents: conceptualising the student role in governance and quality assurance. Higher Education Research \& Development, 1-14, https://doi.org/10.1080/07294360.2020.1792850

Niedlich, S., Kummer, B., Bauer, M., Rieckmann, M, \& Bormann, I. (2020). Cultures of sustainability governance in higher education institutions: A multi-case study of dimensions and implications. Higher Education Quarterly, 74(4), 373-390, https://doi.org/10.1111/hequ.12237

Nugaras, J., \& Ginevičius, R. (2015). The strategic assessment of networking of a higher education institution. Economic Research, 28(1), 31-44, https://doi.org /10.1080/1331677X.2014.995963

Peterson, J. (2003). Policy networks. Vienna, Austria: Institute for Advanced Studies.

Pusić, E. (2005). Upravne organizacije: interakcija - struktura - interes [Administrative organisations: Interaction - structure - interest]. Zagreb, Hrvatska: Društveno veleučilište.

Rhodes, Rod A. W. (1990). Policy networks: A British perspective. Journal of Theoretical Politics, 2(3), 293-317, https://doi.org/10.1177/0951692890002003003

Rhodes, Rod A. W. (2007). Understanding governance: Ten years on. Organizational Studies, 28(08), 1-22, https://doi.org/10.1177/0170840607076586

Rivero, J. (1971). Droit administratif, cinquieme édition. [Administrative law: fifth edition]. Paris, France: Dalloz.

Žugaj, M., Šehanović, J., \& Cingula, M. (2004). Organizacija [Organisation]. Varaždin, Hrvatska: TIVA Tiskara i Fakultet organizacije i informatike.

\section{Legal Sources}

Act on Quality Assurance in Science and Higher Education (Official Gazette 45/09)

Act on Recognition of Foreign Educational Qualifications (OG 158/03, 198/03, 138/06, 45/11). 
Act on the Organisation and Scope of Central State Administration Bodies (OG $85 / 20)$

Act on Scientific Activity and Higher Education (OG 123/03, 198/03, 105/04, 174/04, 2/07, 46/07, 45/09, 63/11, 94/13, 139/13, 101/14, 60/15, 131/17)

\title{
Internet Sources
}

https://mzo.gov.hr/o-ministarstvu/nadleznost-ministarstva-znanosti-i-obrazovan$\mathrm{ja} / 292$

https://mzo.gov.hr/o-ministarstvu/ustrojstvo/53

https://ec.europa.eu/info/departments/education-audiovisual-and-culture_hr

https://www.azvo.hr/hr/o-nama

https://www.mobilnost.hr/

https://www.nvzvotr.hr/hr/aktivnosti

https://www.azvo.hr/hr/savjet-za-financiranje-znanstvene-djelatnosti-i-visokog-obrazovanja

https://www.azvo.hr/hr/odbor-za-etiku

\section{THE ROLE OF AGENCIES IN CREATING NETWORK APPROACH IN HIGHER EDUCATION}

\begin{abstract}
Summary
The possibilities of applying the network approach within the bigher education system are analysed in the paper. A significant part of the paper is devoted to the analysis of public services, their development trends and classification. The situation in the bigher education system is analysed through the inclusion of networking principles and through the establishment of new relevant subjects whose role is to increase the efficiency of public administration. After initial considerations, an overview of the concept of public services now and before is presented along with the classifications of public services and their development through bistory. Furthermore, particular conceptual issues regarding the network approach in public administration are analysed. Emphasis is placed on the network of the bigher education system in Croatia and on different actors as members of such a network: agencies and other subjects relevant for the area of higher education in Croatia (Agency for Science and Higher Education, Agency for Mobility and EU Programs, National Council for Science, Higher Education
\end{abstract}


and Technological Development, Council for Financing Scientific Activity and Higher Education, Ethics Committee in Science and Higher Education). To examine the starting bypothesis that the neo-managerial approach leads to networking within the bigher education system, an empirical study was conducted at the Josip Juraj Strossmayer University in Osijek, Croatia among teaching staff and students. The final chapters of the paper present, summarise and discuss the research results which principally support the initial assumptions.

Keywords: public services, bigher education system, network approach, agencification, public administration

\section{ULOGA AGENCIJA U STVARANJU MREŽNIH ODNOSA U PODRUČJU VISOKOG OBRAZOVANJA}

\section{Sažetak}

U radu se analiziraju mogućnosti primjene mrežnog pristupa u okviru visokoobrazovnog sustava. Znatan dio rada posvećen je sadržajnoj analizi javnih službi, njihovim razvojnim trendovima te samoj klasifikaciji. Stanje sustava visokog obrazovanja analizira se uplivom mrežnih načela $i$ osnivanjem $i$ uključivanjem brojnib relevantnih aktera (subjekata) koji svojom ulogom nastoje povećati učinkovitost tog dijela javne uprave. Nakon uvodnog razmatranja daje se prikaz sbvaćanja javnih službi nekada $i$ danas te se prikazuje klasifikacija javnih službi kao i proces razvoja javnib službi u povijesti. $U$ daljnjem tekstu rada prikazuju se koncepcijska pitanja mrežnog pristupa, odnosno same karakteristike mreža. Nadalje, naglasak je stavljen na mrežu sustava visokog obrazovanja u Republici Hrvatskoj koju čine agencije $i$ ostali akteri koji djeluju u visokom obrazovanju u Hrvatskoj (pregled Agencije za znanost i visoko obrazovanje, Agencije za mobilnost i programe Europske unije, Nacionalnog vijeća za znanost, visoko obrazovanje i tehnološki razvoj, Savjeta za financiranje znanstvene djelatnosti i visokog obrazovanja, Odbora za etiku u znanosti i visokom obrazovanju). Da bi se ispitala polazna bipoteza da neomenadžerski pristup vodi do stvaranja mreža u sustavu visokog obrazovanja, provedeno je istraživanje na Sveučilištu Josipa Jurja Strossmayera u Osijeku među nastavnim osobljem i studentima. Zadnja poglavlja rada prezentiraju i raspravljaju o rezultatima istraživanja koji u načelu podupiru polazne pretpostavke.

Ključne riječi: javne službe, visokoobrazorni sustav, mrežni pristup, agencifikacija, javna uprava 